\title{
Vértakarékos betegellátás a perioperatív szakban
}

\author{
Retteghy Tibor András
}

Országos Orvosi Rehabilitációs Intézet, Budapest

\begin{abstract}
A transzfúzió gyakorlata jelentősen változott az elmúlt két évtizedben. A meglévő anémia és a perioperatív szakban alkalmazott transzfúzió a betegek gyógyulási esélyét csökkentik. A vértakarékos betegellátás programját a vérzés nagy kockázatával járó elektív sebészeti műtétekhez dolgozták ki szerte a világban. A mütét előtt az anémia, az elégtelen vasraktárak és a hemosztázis zavarának kezelése, a beavatkozás okozta vérvesztés csökkentése a program legfontosabb elemei. A vértranszfúzió egy egységenként történő adásának gyakorlata, az intraoperatív vérmentés, és a masszív transzfúziós protokoll, tranexámsav használata, a gondos sebészi hemosztázis, az intraoperatív hypothermia, acidózis elkerülése a program ugyancsak kiemelkedően fontos részei. A jelenlegi ajánlások a megszorító vörösvérsejt-transzfúziós gyakorlatot javasolják a hemodinamikailag stabil sebészeti és belgyógyászati betegeknél, miszerint transzfúzió adása nem szükséges, ha a hemoglobinszint több mint 70-80 g/l. A restriktív transzfúziós gyakorlat megfelelő lehet a legtöbb, anémia tüneteit nem mutató betegnél, csökkenti a transzfúzió adásának kockázatát és nem befolyásolja hátrányosan a mortalitást és morbiditást.. A restriktív transzfúziós gyakorlat megfelelő lehet a legtöbb anémia tüneteit nem mutató betegnek, csökkenti a transzfúzió adásának kockázatát és nem befolyásolja a mortalitást és morbiditást. A vértakarékos betegellátás bevezetése csökkentette az intraoperatív vérvesztést, vérfelhasználást, kórházi kezelés idejét és javította a betegellátás eredményességét. A programot sikeresen vezették be számos európai, amerikai és ausztráliai kórházban. Nincs kétség afelől, hogy kívánatos lenne ez hazánkban is.
\end{abstract}

Kulcsszavak: anémia, vértakarékos betegellátás, megszorító transzfúziós gyakorlat

\section{Perioperative patient blood management}

Transfusion practices changed significantly over the last two decades. The presence of anemia, as well as perioperative blood transfusion reduce the chances of good clinical outcomes. Transfusion practices changed significantly over the last two decades. Patient blood management programs have been developed worldwide for elective surgery at high risk of bleeding. Correction of patient anemia, dysfunctional hemostasis and iron stores prior of surgical procedures, reduction of surgery-related blood loss are key elements of program. Single unit transfusion policy, intraoperative blood salvage, using of massive transfusion protocol, tranexamic acid, meticulous surgical hemostasis, and avoidance of intraoperative hypothermia, acidosis, coagulopathy are of paramount importance in decreasing perioperative blood loss. Current guidelines recommend the use of the restrictive red blood cell transfusion threshold, where transfusions are not indicated if the hemoglobin level is more than $70 \mathrm{~g} / 1-80 \mathrm{~g} / 1$ in haemodynamically stable surgical and medical patients. Restrictive transfusion strategies are appropriate in most patients without signs of anemia, reduce the risk of receiving red blood cell transfusion and has not impact on patient morbidity or mortality. Implementation of patient blood management was associated with a reduction of intraoperative blood loss, utilisation of blood products, length of hospital stay and improved patient outcomes. The program implemented with success in many European, American and Australian hospitals. No doubt it would be also desirable in our country.

Keywords: anemia, patient blood management, restrictive transfusion policy

(Beérkezett: 2018. október 21.; elfogadva: 2018. december 5.)

\footnotetext{
@ Levelezési cím: Dr. Retteghy Tibor András, Országos Orvosi Rehabilitációs Intézet, Budapest, 1121 Szanatórium utca 19.; Tel.: 70-932-3122; E-mail: t.retteghy@gmail.com
} 
Az angolszász irodalomban a Patient Blood Management (PBM) elnevezéssel ismert program lényegét tekintve leginkább vértakarékos betegellátásnak feleltethető meg. A programot eredetileg a sebészeti betegek ellátására dolgozták ki, mely a fejlett egészségüggyel rendelkező országokban az elmúlt évtizedben vált elterjedtté. A kifejezés azt a szerteágazó kezdeményezést jelenti, mely messze nem csupán a megszorító transzfúziós gyakorlattal azonosítható. Egy átfogó program, mely a baleseti sebészetben, szülészetben, és számos eleme a belgyógyászati betegeknél, illetve gyermekeknél is alkalmazható, mely révén a vérkészítmények transzfúziója biztonságosan csökkenthető. A program részletezi azon eszközöket, gyógyszereket, eljárásokat, melyek eredményesen alkalmazhatók a korábbiaknál - a múlt század második felében elterjedtnél - lényegesen takarékosabb vértranszfúziós gyakorlatban.

Maga az elgondolás nem új, a múlt század utolsó két évtizedében több közlemény, illetve egy értékes összefoglaló munka - Mohamed Ramez Salem 1996-ban megjelent könyve - a 90-es években ismert vértakarékos szemléletről, módszerekről ad áttekintést [1]. A jelen megközelítés - az azóta bővülő, tudományos bizonyítékokon alapuló eljárások komplex egységbe foglalása - átfogó, új koncepciónak tekinthető.

A NATA (jelenlegi neve: Network for the Advancement of Patient Blood Management, Haemostasis and Thrombosis, elérhetőségük: http://www.nataonline.com) transzfúziós alternatívák fejlesztésével foglalkozó hálózat, mely 1998-ban alakult meg [2]. Az alapító aneszteziológusok, sebészek, hematológusok és transzfuziológusok szándéka az volt, hogy a vérkomponensek jobb, ésszerúbb, takarékosabb felhasználását segítsék. Ösztönzik a tudományos eredmények, adatok nyílt információcseréjét, így a vértakarékos betegellátást is. A NATA multidiszciplináris fórumot biztosít a vérellátással és vérfelhasználással foglalkozó szakembereknek, hogy elősegítse a klinikai gyakorlat fejlődését a transzfuziológia, illetve az azzal összefüggő folyadékkezelés, hemosztáziszavarok és vénás trombózis megelőzése, kezelése területén.

$\mathrm{Az}$ ausztráliai vérellátást biztosító hatóság (National Blood Authority) finanszírozta és irányította egy 6 modulból álló, az interneten szabadon hozzáférhető irányelvek kidolgozását [3]. Ez tartalmazza az újszülötteknél és gyermekeknél, a szülészetben, a perioperatív szakban, kritikus állapotban, a belgyógyászati ellátásra és a súlyosan vérző, masszív transzfúzióra szoruló betegeknél követendő transzfúziós gyakorlatot. Az irányelvek a szakirodalom és a szakértői konszenzus rendszeres felülvizsgálatát tükrözik.

A vértakarékos betegellátás programja tehát szerteágazó, ezen összefoglaló közlemény a vértakarékos sebészeti ellátás lehetőségeit tekinti át.

A program alább részletezett három fő pillére (eleme): - az anémia preoperatív kezelése, az optimális hemosztázis biztosítása,

- az intra- és posztoperatív vérvesztés csökkentése, ill. minimalizálása,

- az anémia tolerálása érdekében a beteg fiziológiai tartalékainak kihasználása, az oxigénkínálat növelése és az oxigénfogyasztás csökkentése, a szívperctérfogat optimalizálása, a vérkészítmények korszerü ajánlásokkal összhangban történő megszorító, racionális alkalmazása.

A program három eleme az egész perioperatív szakra ad ajánlásokat, melyek egyes részei - érthető módon esetenként azonosak (ld. 1. táblázat). A vértakarékos ellátás három fő pillére a következő.

1. táblázat. A perioperatív vértakarékos betegellátás három eleme

A perioperatív vértakarékos betegellátás három eleme

\begin{tabular}{|c|c|c|}
\hline $\begin{array}{l}\text { - az anémia és a hemosztázis zavarainak } \\
\text { preoperatív korrekciója, } \\
\text { - eritropoezis segítése: vaspótlás, EPO (?), } \\
\text { - vérzékenységet növelő, anémiát okozó } \\
\text { gyógyszerek lehetőség szerinti elhagyá- } \\
\text { sa, körültekintő alkalmazása, } \\
\text { - preoperatív autológ donáció (?) }\end{array}$ & $\begin{array}{l}\text { - a perioperatív vérvesztés csökkentése, } \\
\text { - autológ vérmentés, } \\
\text { - masszív transzfúziós protokoll használata, } \\
\text { - hemosztázis korszerü, gyors diagnosztiká- } \\
\text { ja, kezelése, } \\
\text { - vérzést csökkentő gyógyszerek, aneszte- } \\
\text { ziológiai és sebészi eljárások alkalmazása, } \\
\text { - normothermia biztosítása, } \\
\text { - vörösvérsejt-transzfúzió: stabil betegnél } \\
\text { egy egységenként }\end{array}$ & $\begin{array}{l}\text { - az anémia fiziológiás toleranciájának } \\
\text { segítése: } \\
\text { oxigénkínálat növelése és az } \mathrm{O}_{2^{-}} \\
\text {fogyasztás csökkentése, } \\
\text { optimális perctérfogat biztosítása, } \\
\text { - megszorító transzfúziós gyakorlat }\end{array}$ \\
\hline
\end{tabular}

\section{Elem: az anémia, a hemosztázis zavarainak mútét előtti korrekciója}

Az Egészségügyi Világszervezet (World Health Organization, $W H O$ ) definíciója szerint anémia alatt felnőtt nőknél $120 \mathrm{~g} / \mathrm{l}$ alatti, férfiaknál $130 \mathrm{~g} / \mathrm{l}$ alatti hemoglobin értendő.
Az anémia mütét előtt álló betegek körében meglehetősen változó, a mütét típusától, populációtól függően átlagosan 35\%-os gyakoriságú [4]. Egyértelmű adatok vannak arra vonatkozóan, hogy az általános sebészeti, orthopédiai, nőgyógyászati mütétre kerülő betegeknél a preoperatív anémia a kedvezőtlen kimenetel egyik független koc- 
kázati tényezője. Paradox módon az anémia transzfúzióval történő korrekciója a morbiditást és mortalitást ugyancsak növelheti, tehát lehetőség szerint szintén kerülendő [5-8]. Ezen ismeretek birtokában érthető, hogy a nem sürgősséggel, hanem tervezett időben végezhető mütétre kerülő betegeknél diagnosztizált, nem korrigált anémia a beavatkozás ellenjavallatát képezi.

A vérszegénység korai, a mütét előtt egy hónappal megkezdett kivizsgálás során történő felismerése, majd kezelése elfogadott gyakorlattá vált számos fejlett egészségüggyel rendelkező országokban. Az erre vonatkozó szakmai ajánlások egyértelmúek: arra kell törekedni, hogy a betegek optimális hemoglobinértékkel ( $\geq 130 \mathrm{~g} / \mathrm{l})$ kerüljenek a vélelmezhetően számottevő vérzéssel járó mütéti beavatkozásra. A vértranszfúzió szükségességével, várhatóan 500 ml-nél nagyobb volumenü vérvesztéssel járó, tervezett időben végezhető mütéti beavatkozást tehát részletes kivizsgálásnak kell megelőznie [3, 4, 9].

Amennyiben a beteg anémiás, a mútét halasztása erősen javasolt, ezért a mütéti program jobb tervezhetősége érdekében a preoperatív kivizsgálást idejében kell megkezdeni. Az anémia kivizsgálását az abban kellően jártas belgyógyász, aneszteziológus, sebész vagy leginkább hematológus végezheti. Eredményes kezelést követően a mütét elvégezhető [10].

\section{Hiányanémiák: kivizsgálás és kezelés}

A vérszegénység számos betegség velejárója, a vashiány csak az egyik, bár a leggyakoribb tényező. Abszolút vashiányban a vasraktárak állapotát mutató ferritin szintje $30 \mu \mathrm{g} / 1$ alatti. Gyulladásos betegség egyidejü fennállása esetén a ferritin szintje - mivel akut fázis fehérje - megemelkedhet, de a transzferrinszaturáció (a vasszállító fehérje telítettsége - TSAT) alacsony, 20\% alatti. A ferritinszint különösen magas lehet rákbetegségben, akut infekció és veseelégtelenség esetén is. A vashiány szürése első lépésben a számos helyen elérhető egyszerű hematológiai vizsgálatokkal, a ferritin és a TSAT mérése alapján történhet. Amennyiben a szérum ferritin $<100 \mu \mathrm{g} / \mathrm{l}$ és a TSAT $<20 \%$, a diagnózis megerösítettnek tekinthető. Krónikus gyulladásos állapot esetén, ha a ferritin 100 $300 \mu \mathrm{g} / \mathrm{l}$ közötti, az alacsony TSAT vashiány mellett szólhat [8]. A CRP ekkor emelkedett, de pontos diagnosztikus határértéke nem ismert, ezért meghatározása a javasolt rutinvizsgálatoknak nem feltétlenül része. Magasabb ferritinszintnél (>150 nőknél, >200 $\mu \mathrm{g} / \mathrm{l}$ férfiaknál) a TSAT feltétlenül meghatározandó (mint májbetegség, elhízás és idős kor esetén is), a téves diagnózis csapdája így elkerülhető. Ha a vasraktárak tovább csökkennek, microcytaer és hypochrom anémia alakul ki.

A funkcionális, vagy látens vashiány szakértői vélemények és racionális megfontolások alapján is kezelendőnek tekinthető a perioperatív szakban [10].

A mütét után a már korábban megkezdett vaspótlás folytatása, vagy akár a vérvesztéssel arányos megkezdése is hasznos lehet. Ebben nagy segítség lehet a korszerü, kevés mellékhatással bíró, nagy mennyiségü elemi vasat tartalmazó vénás készítmények, melyekkel az enterális vas hasznosulásának zavara okozta kudarc elkerülhető. Több vizsgálat és szakértői vélemény szerint az enterális bevitel hátrányaival (intolerancia, bizonytalan effektivitás) nem rendelkező, bár nagyobb költségvonzatú vénás készítményeknek helye van a perioperatív ellátásban is [10-12].

Egy randomizált, kontrollált vizsgálatban vashiányos anémiás, nagy hasi mütéten áteső betegeknél a vérveszteség arányában végzett vénás vaskezelés hatását vizsgálták a közvetlen perioperatív szakban. A mortalitásban és morbiditásban nem találtak különbséget, de a kezeltek csoportjában az allogén transzfúzió szükségessége és a kórházi kezelés hossza csökkent, a hemoglobinkoncentráció emelkedett [12].

B12-vitamin- és folsavhiány, krónikus betegségek (infektív és nem infektív gyulladások, malignus betegségek, egyes máj- és szívbetegségek), ritkábban gyógyszerhatás (pl. metformin, angiotenzin-konvertáló enzimgátlók, nem szteroid gyulladásgátlók), okkult vérzés, ritkán (immun) hemolízis, mind szerepet játszhat az esetenként multifaktoriális anémia kialakulásában.

\section{Eritropoézist stimuláló ágensek}

Eritropoézist stimuláló ágens (ESA) alkalmazása leginkább az idült betegségekhez társuló anémia kezelésekor jöhet szóba a perioperatív szakban. Az egyes ESA-készítmények hazai törzskönyvezett indikációi valamelyest eltérőek. A forgalomba hozatali engedélyben jóváhagyott alkalmazási előiratban a mütéti előkészítéssel kapcsolatban két indikáció került említésre: a) az autológ transzfúzió céljából végzett preoperatív vérgyüjtés segítésére és b) nem vashiányos, a transzfúzió szövődményei miatt előreláthatólag jelentős kockázatnak kitett felnőtt, elektív nagy orthopédiai mütétre váró betegek esetén az allogén transzfúziós igény csökkentése.

Az eritropoézis gyógyszeres serkentése a palliatív kezelésre szoruló, jelentős anémiával járó, előrehaladott rosszindulatú betegségben szenvedőknél elfogadottnak minősül. Potenciális mellékhatásai ( $\mathrm{pl}$. thromboembólia, hipertónia, tumor angiogenezisének serkentése) miatt az ESA a kuratív onkológiai terápiának nem része, mivel a mortalitást növelheti: szimptomatikus anémiában a transzfúzió a választandó kezelés. A rövidebb idejü perioperatív szakban történő alkalmazás veszélyei megfelelő vizsgálatok hiányában nem ismertek, így egyértelmű állásfoglalás nem tehető. A visszafogottnak tekinthető brit ajánlás szerint, ha a transzfúzió elkerülésének erős javallata van (beteg elutasítja, komplex alloimmunizáció) a preoperatív ESA-kezelés indokolt lehet [13]. Végstádiumú vesebetegeknél a potenciális mellékhatások csökkentése érdekében arra törekednek, hogy a kezelés során a hemoglobinérték ne emelkedjen 120-130 g/l fölé. Ezen ajánlás talán a preoperatív szakra is vonatkoztatható, mely így megfontolás tárgya lehet. 
Egy kissé szimplifikált, de kétségtelenül pragmatikus megoldásnak tünik a zürichi Balgrist Egyetemi Kórházban bevezetett gyakorlat. A nagy orthopédiai, illetve gerincsebészeti műtétre váró anémiás betegeknél a mütéti előkészítést 4 héttel a tervezett beavatkozás előtt kezdték meg. Ennek során - a speciális hematológiai kivizsgálást mellőzve - 1000 mg iv vas-karboximaltóz és 40000 nemzetközi egység erythropoietin alfa, illetve $1 \mathrm{mg} \mathrm{B12-vita-}$ min adására került sor, mely kezelés naponta $5 \mathrm{mg}$ folsav adásával egészült ki. Az első vérkép kontrollt 14 nap elteltével végezték: perzisztáló anémia esetén a vénás vas, eritropoetin és B12 adását megismételték. A program a szokásos vértakarékos intraoperatív eljárásokkal (cell saver és/vagy helyi haemostaticus gyógyszerek használata) és standardizált transzfúziós trigger alkalmazásával egészült ki (tranexámsavat és posztoperatív vérmentést ebben az időszakban még nem alkalmaztak). A program sikeresnek volt minősíthető, a mütét napján a hemoglobinkoncentráció a kívánt $130 \mathrm{~g} / \mathrm{l}$-t minden betegnél elérte vagy meghaladta, a vérveszteség, illetve a homológ vértranszfúzió szükségessége szignifikánsan csökkent [14].

\section{Elem: a perioperatív vérvesztés csökkentése}

\section{Autológ vérgyüjtés, vérmentés, massziv transzfúzió, a hemosztázis kontrollja és biztositása, koagulációs faktorok pótlása}

Elvben a preoperatív autológ donáció (PAD) is e program része. Az autológ hemoterápia e formájának megítélése az elmúlt években azonban jelentősen módosult. Az újabb ajánlások jó része a kellő effektivitás hiánya (és a homológ transzfúzió biztonságosságának további javulása) miatt rutinszerü használatát nem, legfeljebb válogatott esetekben és betegeknél javasolják, ennek megfelelően alkalmazása az elmúlt másfél évtizedben drasztikusan visszaszorult. Nagyobb vizsgálatok szerint a PAD hatékonysága erősen vitatható, mivel az előzetesen lebocsátott vér $20-50 \%$-a nem kerül felhasználásra. Emellett a vérlebocsátásokat követően a betegek jelentős hányada anémiásan kerül mütétre, mely így az autológ mellett a homológ vértranszfúzió szükségességének esélyét is növeli. Jelen megítélés szerint a preoperatív vérgyüjtést leginkább az allogén vér biztosításának szerológiai nehézségei (ritka ellenanyagok a recipiens vérében) vagy a beteg kifejezett kérése indokolhatja [15-17]. Az 1980-as évek végén, az 1990-es évek elején az átvihető vírusbetegségektől való félelem miatt az autológ hemoterápia iránti érdeklődés rendkívül megnőtt, majd a veszély drasztikus enyhülésével - különösen a 2000-es évek elejétől - látványosan csökkent. Az Egyesült Államokban és Kanadában a PAD 2013-ban az összes véradásnak kevesebb, mint 0,3, illetve 0,1 százaléka volt. Európában a tendencia ehhez nagyon hasonló volt: a 2000-es évek elején még 1,6-6,8\% volt, ami Olaszország kivételével 2013-ra 0,5\% alá csökkent [18].
Hazánkban a PAD népszerüsége a nyugat-európaihoz képest mindig jóval szerényebb volt, a csökkenő tendencia viszont itt is megfigyelhető: míg 2015-ben 682, 2017ben 432 egység került lebocsátásra, mely az összes vérvételek csupán 0,11\%-át jelentette (dr. Nagy Sándor, Országos Vérellátó Szolgálat, személyes közlés, 2018. 11. 28.).

A vérzés, vérzékenység kockázatának felmérése, időben történő kezelése a mütéti előkészítés egyik alapvetően fontos eleme. A vérzést fokozó antikoaguláns, antiaggregációs hatású gyógyszereket mütét előtt kellő időben le kell állítani, de utóbbi ágenseket csak akkor, amennyiben az adott betegnél a vérzés kockázata meghaladja a trombózis kockázatát. A veleszületett és szerzett koagulációs zavarok esetén a szubsztitúciós kezelést a kockázat arányában kell megtervezni. A preventív célú szubsztitúciós kezelés haszna bizonyos esetekben - elsősorban májbetegeknél - erősen vitatott, rutinszerű alkalmazása nem javasolt, de ennek részletezése meghaladná e dolgozat tervezett kereteit.

A desmopressin enyhe és középsúlyos hemophilia A és von Willeband-betegségben (kivéve $2 \mathrm{~B}, 3$ típus) szenvedők és az urémiás eredetü vérzékenység csökkentésére alkalmas. A clopidogrel vagy acetilszalicilsavaggregációgátló kezelés alatt álló betegeknél használata $0,3 \mu \mathrm{g} / \mathrm{ttkg}$ dózisban (esetleg adjuvánsként tranexámsav használatával) a vérzést - sporadikus közlemények, illetve egy metaanalízis szerint - a szívsebészeti betegek körében csökkentheti, így használatával az aggregációgátlás átmeneti felfüggesztése megkísérelhető [19], de a prasugrel és ticlopidin hatásának felfüggesztésére alkalmatlan. Tény, hogy a desmopressinnel kapcsolatban kevés adat áll rendelkezésre, vélhető, hogy ez az erős bizonyítékokkal nem alátámasztott javaslat nem szívsebészeti betegekre is extrapolálható.

A gyógyszeres vérzéscsillapitás egyik legfontosabb tagja a fibrinolízist gátló szintetikus lizinanalóg tranexámsav, mely elsősorban a lokális vagy generalizált hyperfibrinolysis esélyével járó vérzések megelőzésére és kezelésére használható. Ilyenek többek között a nagy orthopédiai, máj- és szívsebészeti mütétek, a menorrhagia és metrorrhagia, húgyúti infekcióhoz társuló vérzés, a nőgyógyászati és szülészeti vérzések és számos posztoperatív szakban fellépő vérzés, pl. a prosztata-, húgyúti sebészet, fül-orr-torokban végzett mütétek is [20]. Korai használata súlyos sérülteknél a mortalitást csökkentheti [21]. Gastrointestinalis vérzésben való alkalmazhatóságának megítélésében egy még nem befejezett vizsgálat (HALT-IT) eredményei fognak remélhetőleg segíteni.

Az ún. kármentő sebészet (damage control surgery) a baleseti sebészetben az ellátás taktikáját részben megváltoztatta. A vérzések forrását a mütét lerövidítésével, speciális eszközök, eljárások alkalmazásával megszüntetve a vérzéscsillapítást és a hemosztázist abszolút prioritásként kezeli. Jelen megítélés szerint ezt a szöveti hypoperfusio, illetve a coagulopathia viszkoelasztikus hemosztázis vizsgálatokon (thrombelastographia és rotációs thrombelas- 
tometria) alapuló gyors, differenciált kezelése, a dilúciós coagulopathia elkerülése és valószínúleg a korai fibrinogénpótlás is segítheti [22-26].

$\mathrm{Az}$ intraoperatív szakban a megfelelö, vértakarékos sebészi technika, a vérzést fokozó tényezők elkerülése, korszerü helyi hemosztatikus hatású gyógyszerek, eszközök és módszerek (pl. fibrinragasztó, minimálisan invazív eljárások, diatermiás kés, ultrahangos vágóeszköz) használata, a hipertenzió, coagulopathia, hypothermia elkerülése a gazdaságos hemoterápia fontos elemei. A vazokonstriktortartalmú lokálanesztetikum használata nem csak a vérvesztés csökkentésének, hanem a posztoperatív fájdalomcsillapításnak is része lehet.

$\mathrm{Az}$ autológ transzfúziós eljárások közül a preoperatív hemodilúció önmagában kevéssé, az intraoperatív vérmentés (cell saver) azonban jelenleg is különösen hasznosnak minősül a homológ vértranszfúzió elkerülésében [17, 22]. Hazai használatáról nincsenek megbízható, pontos adatok, de alkalmazásának elterjedését a homológ vérkészítményeknél lényegesen magasabb költségvonzata biztosan nem segíti.

A masszív transzfúziós protokoll a kritikus állapotú vérző betegek ellátásának, a hemosztázis és keringés helyreállításának, a prioritásokat, az alkalmazandó vérkészítményeket részletesen tartalmazó program [21, 22]. Jelen ismereteink szerint a diagnosztikai és klinikai eljárásrendet az adott egészségügyi intézmény körülményeit figyelembe véve javasolt kidolgozni, szükség szerint - az újabb, bizonyító erejü kutatási eredmények birtokában felülvizsgálni és módosítani. Használata bizonyítottan csökkentheti a mortalitást és morbiditást, a kórházi, intenzív osztályos kezelés és a lélegeztetés idejét és a felhasznált vérkészítmények számát a traumatológiában, szülészetben és a gastrointestinalis vérzések ellátása során is.

$\mathrm{Az}$ aneszteziológiai eljárások közül a kontrollált hypotensio és a neuroaxiális anesztézia említendő. Az előbbi nem teljesen veszélytelen eljárás, más vértakarékos eljárások mellett az utóbbi időben - részben érthető módon - háttérbe szorult, bár kellően válogatott betegeknél alkalmazva biztonságosnak tekinthető. A neuroaxialis anesztézia megítélése egyértelműbb: a rendelkezésre álló vizsgálatok eredményeiből készített összesített elemzés szerint alkalmazása az intraoperatív vérvesztést csökkenti [27].

$\mathrm{Az}$ elsősorban a szívsebészetben, májtranszplantáció során és traumatológiában elterjedten használt viszkoelasztikus hemosztázisvizsgálatok a standard globális alvadási vizsgálatoknál több információt adnak. Perioperatív használatuk csökkentheti a felhasznált vérkészítmények számát, és a morbiditást. Klinikai vizsgálatok által kellően alátámasztott bizonyítékok a szívsebészeten kívül (még) nincsenek, de a vonatkozó új brit ajánlás pragmatikus információkat ad a klinikai gyakorlathoz [24].

Súlyos sérülésekhez társuló koagulációs zavar és jelentős vérzés eseteiben az FFP helyett teoretikusan alvadási faktorkoncentrátumok is használhatók. Ezek közül elsősorban a korábban már említett fibrinogénnel kapcsolat- ban vannak pozitív eredményü, bár nem nagy esetszámú vizsgálatokról beszámoló közlemények [23, 25, 26]. A jelen megítélés szerint a PCC önállóan nem, az aktívált VII-es faktorkoncentrátum csak kivételes, minden más kezelésre nem reagáló esetekben, a XIII-as faktor adása pedig nem javasolt [26]. A még korántsem lezárt kérdés azonban további vizsgálatok tárgya kell legyen.

\section{A transzfundált vörösvérsejt készitmények egyszeri adagjának csökkentése}

Több mint fél évszázados dogma szerint a vörösvérsejtkoncentrátum transzfúziója során legalább két egység szükséges a korábban elérendőnek vélt 100 g/l-es hemoglobinértékhez. A szemlélet az elmúlt bő két évtizedben alaposan megváltozott: a transzfúziós trigger (a transzfúzió indikációját jelző hemoglobinérték) jelentősen, 7080 g/l-re csökkent. Ennek elérése - különösen idősebb, illetve alacsonyabb testtömegü, nem extrém anémiás betegeknél - stabil állapotú, aktuálisan nem vérző betegeknél csupán egy egység adásával is lehetséges [3, 28, 29]. Fontos megjegyezni, hogy az intra- és posztoperatív szakban fellépő aktív vérzés eseteire mindez természetesen nem vonatkozik.

A restriktív transzfúziós politika elterjedése ellenére a transzfúzió okozta keringéstúlterhelés a kórházi morbiditásnak (hosszabb intenzív és kórházi kezelés és gyakoribb lélegeztetés) és mortalitásnak független kockázati tényezője maradt. A kockázatok között a heveny vesekárosodás, sürgősségi sebészeti beavatkozás, diuretikumkezelés, kardiovaszkuláris érintettség, jelentősebb pozitív folyadékegyensúly, májelégtelenség, plazmatranszfúzió szerepel [29]. A keringés túlterhelése szempontjából magas kockázatú betegeknél az egy egységenként történő vörösvérsejt-transzfúzió különösen ajánlott. Sőt, a célérték lényeges meghaladása egyenesen nem kívánatos, téves döntésnek, hibának tekintendő. Az egy egység adásával kezdődő, s csak a vérkép kontroll- és klinikai vizsgálat alapján elégtelennek minősülő hatás miatt egy újabb, önálló döntésen alapulva folytatott transzfúzió tehát elfogadott, standard gyakorlattá vált szerte a fejlett világban $[3,28,29]$. A friss fagyasztott plazma (FFP) transzfúziója szintén jelentős, tartós volumenterhelést jelenthet. A K-vitamin antagonista antikoagulánsok hatásának felfüggesztésére egyidejüleg több egység FFP transzfúziója szükséges, mely a keringéstúlterhelés fellépésének esélyét növeli. A kumarinszármazékok hatásának felfüggesztése prothrombin komplex koncentrátummal (PCC) vélhetőleg legalább annyira hatásos és biztonságos, ugyanakkor az FFP-nél lényegesen gyorsabb hatásbeállással lehet számolni. Ezen megfontolásokból logikusnak tűnik a PCC használata a keringés túlterhelésének veszélye esetén, mint például intracranialis vérzésben szenvedő vagy nem vérző, de sürgősséggel végzendő mütétre váró betegeknél. 


\section{Elem: az anémia fiziológiás toleranciájának biztosítása}

\section{Megszoritó transzfúziós gyakorlat}

A megszorító transzfúziós gyakorlat a vértakarékos eljárások legfontosabb eleme, alkalmazása a betegek döntö hányadában - a perioperatív szakban, szülészetben, a kritikus állapotú betegeknél, gyermekeknél és a belgyógyászat minden területén - érvényes princípium.

A klinikai transzfuziológiában joggal mérföldkőnek tekintik a Kanadában végzett, nagy multicentrikus, intenzív osztályos ellátásra szoruló betegek körében végzett vizsgálatot. Ebben bizonyítást nyert, hogy a megszorító transzfúziós gyakorlat a hagyományos liberális gyakorlatnál a morbiditás, a mortalitás tekintetében egyáltalán nem kedvezőtlenebb, sőt a vizsgálatba bevont kevésbé súlyos állapotú, illetve 55 év alatti betegeknél a halálozás alacsonyabb volt [30].

A Jehova Tanúi Egyház tagjainak vértől való tartózkodása lehetővé tette, hogy a klinikusok a vértakarékos eljárások alkalmazásában kellő gyakorlatot szerezhessenek, mely révén a vérkészítményt nem elutasító betegek ellátása is biztonságosabbá válhatott. A közel háromszáz, 61,5 átlagéletkorú, túlnyomórészt a Jehova Tanúi Egyház tagjai körében végzett retrospektív vizsgálat fontos adatokat szolgáltatott a súlyos fokú anémia következményeire vonatkozóan. Amennyiben a posztoperatív szakban a hemoglobin 70-80 g/l között volt, a 30 napos halálozás csupán 1\%-os, 50-70 g/l hemoglobinszint között 9,2\%-os, 30-50 g/1 között közel 27\%-os volt [31]. Más vizsgálatok eredményeivel megegyezően tehát úgy tünik, hogy a hemoglobin kritikus határértéke normovolaemia esetén valahol $60 \mathrm{~g} / \mathrm{l}$ körül van.

Jelen megítélés szerint a vörösvérsejt-koncentrátumok restriktív alkalmazása - 70-80 g/l közötti hemoglobinra való törekvés - a hemodinamikailag stabil betegek széles körében biztonságosnak minősül. Ez a megállapítás nemcsak a szoros monitorozást igénylő kritikus állapotúakra, hanem a súlyos, de (már) nem vérző, stabil hemodinamikai állapotban lévő sérültekre, súlyos fertőzésben szenvedőkre, idősebbekre és gyermekekre is egyaránt vonatkozik [21, 28, 30, 32-34].

A felső gasztrointesztinális traktus heveny vérzésének ellátási taktikája az utóbbi években módosult. A korai endoszkópos vizsgálat és beavatkozás, a koagulációs zavarok gyors, viszkoelasztikus módszerrel történő diagnosztikája elterjedt gyakorlattá vált. A masszív kivérzéssel nem járó esetekben, illetve az elörehaladott verőérbetegségben nem szenvedő betegeknél végzett spanyol vizsgálat szerint a megszorító transzfúziós politika biztonságosnak minősül, a túlélés esélye a Child-Pugh szerint A és B stádiumba sorolt májcirrhosisban szenvedőknél egyértelműen kedvezőbb volt [35].

A megszorító gyakorlat javaslata nem vonatkozik: - heveny koszorúér tünetegyüttesben,
- vérzés veszélyével járó súlyos thrombocytopeniás onkológiai/hematológiai betegségben szenvedőkre,

- illetve a krónikus transzfúziódependens anémiás betegekre,

melyeknél az elérendő hemoglobinszint nem ismert [28], de a 80-90 g/l, esetleg afölötti hemoglobinra való törekvés erősen megfontolandó. A restrikció az instabil keringéssel járó súlyos vérzés, masszív transzfúzió során a nehezen megbecsülhető keringő vértérfogat, az anémia és hypovolaemia esetleges együttes előfordulása miatt rendkívül veszélyes lehet. A központi idegrendszer heveny megbetegedéseiben, így agysérülteknél, illetve subarachnoidealis vérzés eseteiben a biztonságos hemoglobinérték nem ismert. A cerebrális szöveti oxigénnyomás, oxigénszaturáció vagy mikrodialízissel végzett monitorozás ez irányú haszna egyelőre bizonytalan. A cerebrális ischaemia veszélye esetén a klinikusok napi gyakorlatában a transzfúziós trigger érthető módon meglehetősen változó, részben vérmérséklettől, másrészt elvi megfontolásoktól függően 70-100 g/l közötti [36]. Az érvényes, 2016-ban kiadott európai útmutatás a súlyos koponyasérültek hemoterápiájára vonatkozóan gyenge bizonyítékokon nyugvó, de erôsebb ajánlásként ugyanakkor a megszorító gyakorlatot javasolta [21].

A restriktív transzfúziós politika a posztoperatív szakra is érvényes követelmény. Az egyes betegek aktuális állapotára, teherbíró képességére szabott kezelés, a fiziológiás tartalékok, kockázatok felmérése, a perctérfogat, így az oxigénkínálat optimalizálása, restriktív transzfúziós küszöbérték tartása mind fontos elvárás lehet. Az oxigenizáció, ventiláció optimalizálása, az oxigénfelhasználás növekedését okozó láz, remegés, fájdalom elkerülése, az optimális szívperctérfogatra való törekvés a program további részét képezik [3, 37].

\section{További megfontolások}

A iatrogén vérvesztés elkerülését a laboratóriumi vizsgálatokhoz hagyományosan használt vérvételi csövek helyett a kisgyermekeknél alkalmazott kisebb térfogatú mintavevő csövek használata és a vérvételek racionalizálása szolgálhatja.

A posztoperatív ellátás során talán kevesebb figyelem esik a vértakarékos szemlélet minden, e periódusra vonatkozó elemére [37, 38]. A további anémizálódás nagyobb beavatkozások után multifaktoriális eredetü lehet, utóvérzést a sebészi ellátás hiányossága mellett dilúciós, esetleg hypothermia okozta coagulopathia is okozhat $[3,37]$. A redon drain korábban elterjedt használatával a posztoperatív vérvesztés növekszik, rutinszerü alkalmazását több orthopédiai centrumban megszüntették.

A vaspótlás megkezdése alapvetően a preoperatív szak feladata, de a vérvesztéssel járó vashiány pótlása szintén indokolt lehet [37]. Jól ismert, hogy minden $1 \mathrm{ml}$ vér elvesztése $0,5 \mathrm{mg}$ elemi vas elvesztésével jár (150 g/l-es hemoglobinkoncentráció esetén), mely pótlása a közvetlen posztoperatív periódusban a bizonytalan hasznosulás 
miatt elsősorban vénásan történhet. Khalafallah és munkatársai egy 200 beteg bevonásával végzett prospektív randomizált vizsgálatban úgy találták, hogy egy egyszeri nagyobb dózisú, 800-1000mg intravénás vas-karboximaltóz adása nagy orthopédiai, hasi, urogenitális sebészeti beavatkozások után szignifikánsan emelte a hemoglobinkoncentrációt, csökkentette a homológ transzfúzió szükségességét és végső soron a kórházi kezelés hosszát [39]. Aktuálisan fennálló fertőzés a vaspótlás ellenjavallatát képezheti. Tény, hogy a vaskészítmények baktériumok növekedését és virulenciáját segítő hatásának klinikai relevanciáját sokan kétségbe vonják. A nem kis részben experimentális vizsgálatokon nyugvó aggodalmak jórészt teoretikusak [40]. Mivel nincsenek megcáfolhatatlan adatok a vaskészítmények ártalmairól, de fertőzésben történő használatuk előnyös voltáról sem, így egyelőre (még) a tartózkodó álláspont tűnik bölcsebb választásnak. E megállapítás különösen a súlyos infekcióban szenvedő vagy immunkompromittált, transzplantáció után lévő vagy neutropéniás betegekre vonatkozik.

$\mathrm{Az}$ intraoperatív vérmentés a mütét utáni szakban is folytatódhat. A mosott vörösvérsejt-koncentrátumot elöállító, már említett cell saver használata biztonságos, hazánkban is számos helyen alkalmazott gyakorlat. Másik formája a mütéti területről elszívott vér speciális vérvételi zsákba történő, csak mechanikai szűrésen áteső mentése, mely az előbbivel ellentétben mosási fázison nem esik át. A számos gyártó által kifejlesztett és forgalmazott egyszer használatos vérvételi zsákok egyben a teljes vér retranszfúziójára alkalmas eszközök. A mütéti területről mentett vér nem kevés szabad hemoglobint tartalmaz, változó, de nem ellenőrizhető minőségű, vörösvérsejtekben relatíve szegény, de káros biológiailag aktív kontaminánsokban „gazdagabb”, potenciálisan veszélyesebb készítmény. Ugyanakkor az esetleges mellékhatásoknak, szövődményeknek nincs jelentési kötelezettsége. Érthető, hogy több szakértőben kételyek merültek fel a teljes vér retranszfúziójának kellő biztonságosságát illetően [41], jóllehet, több publikált esetszéria szerint biztonságos, és megfelelően alkalmazva kimutatható homológ vérmegtakarító hatású. A szívsebészetben használatát megszüntették, de az orthopédiai mútéteknél jelenleg is választható eljárásnak minősül.

\section{Restriktív transzfúziós politika, vértakarékos ellátás - az érem másik oldala}

A klinikai transzfúziológiában (is) bőven vannak még megválaszolatlan kérdések. Az anémiára adott fiziológiás válasz több kísérőbetegség, vagy gyógyszeres kezelés (pl. béta-blokkoló, kálciumcsatorna-blokkoló kezelés) miatt részben módosulhat, ill. akár el is maradhat. A már korábban idézett nagy multicentrikus vizsgálatok szerint a betegek túlnyomó többsége a megszorító transzfúziós gyakorlatot - a mérsékelt (hemoglobin: 80-100 g/1) és a betegek jelentős része a súlyos vérszegénységet is $(70-80 \mathrm{~g} / \mathrm{l})$ - jól tolerálja. Ugyanakkor jelenlegi tudásunk szerint nincs olyan megbízható biomarker, mely az anémia káros hatását, a szöveti oxigénkínálat elégtelenségét (ellentétben a szérum laktáttal és báziseltéréssel) valóban korán és biztosan, megfelelő szenzitivitással és specificitással jelezné. Egy szívsebészeti mütétek során végzett klinikai vizsgálatban a hemoglobin csökkenése és a plazma methemoglobinszint-emelkedése között észlelt korreláció felvetette utóbbi potenciális szerepét az anémia okozta szöveti oxigenizációs zavarok korai detektálásában [42]. Használhatóságról, klinikai alkalmazásról azonban még nagyon korai lenne vélekedni.

Jól ismert, hogy krónikus anémiánál van idő a kompenzációs mechanizmusok kialakulására. A nyugalomban szervdiszfunkciós tünetekkel egyáltalán nem járó idült vérszegénység esetén a stabil állapotú, nem nagy kockázatú, az adekvát gyógyszeres kezelésre várhatóan 7-10 napon belül reagáló betegeknél a transzfúzió általában elkerülhető. Ez a megállapítás már kevéssé vonatkoztatható a vérvesztés okozta akut anémiára, mely lényegesen veszélyesebb. Hasi sebészeti betegeknél végzett vizsgálat szerint a súlyos fokú ( $\geq 50 \%$-os), de a 70 g/l-es transzfúziós trigger alá nem csökkenő hemoglobinérték a morbiditást (a cerebrovaszkuláris és miokardiális iszkémiás események előfordulási gyakoriságát) növelheti [43].

$\mathrm{Az}$ oxigénkínálat és -fogyasztás szervenként eltérést mutathat. Az intenzív osztályon kezelt betegeknél a centrális vénás oxigénszaturáció $\left(\mathrm{ScvO}_{2}\right)$ mérése-monitorozása elterjedt gyakorlat, bár - fontos megjegyezni - csak a globális oxigénkínálat és szükséglet viszonyának mutatója. $\mathrm{Az} \mathrm{ScvO}_{2}$ aktuális értéke csak a metabolikus (szérumlaktát és báziseltérés) és hemodinamikai vizsgálatok eredményeivel összevetve adhat információt. Normovolaemia esetén az $\mathrm{ScvO}_{2}$ fiziológiásnál alacsonyabb, 65-70\% alatti értéke az oxigénkínálat és -felhasználás egyensúlyának megbomlására utalhat. Információs értéke korlátozott, de mérsékelt, ill. súlyos fokú anémia esetén - amennyiben a keringő vértérfogat és szívperctérfogat megfelelő - a transzfúzió szükségességét jelezheti [44, 45].

A vérmentés, a korszerű intravénás vaskészítmények és az ESA költségei meglehetősen magasak. A fejlett európai országokban a vérkészítmények ára változó, de a hazaiaknak többszöröse, mely a vértakarékos módszerek költséghatékonyságának itthoni megítélését erősen torzíthatja. Egy felmérés szerint Nyugat-Európában két egység vörösvérsejt-koncentrátum transzfúziója (beleértve az összes járulékos költséget is) tetemes, megközelítőleg 800 euró [46].

\section{A vértakarékos betegellátás a nagyobb klinikai vizsgálatok tükrében}

A vértakarékos szemléletet tükröző, minden lehetséges eljárást tartalmazó programot Ausztriában 2005-ben, Linzben vezették be, ahol a rákövetkező hat évben a vérfelhasználást 60-70\%-kal sikerült csökkenteni [47].

Egy másik, említésre méltó vizsgálat a program négy németországi centrumban történő bevezetését megelőző 
és követő időszakának eredményeiről számolt be. A 2016-ban publikált vizsgálat szerint hasznos, a felhasznált vörösvérsejt-koncentrátumok számát érdemben csökkenteni képes, a betegek számára biztonságos programnak bizonyult. A betegek felépülése a korábbi időszakhoz képest jórészt azonos volt, de a heveny vesekárosodás incidenciája csökkent [48].

Az ebben a témában valaha készült legnagyobb, több mint 600000 beteg bevonásával készült retrospektív vizsgálat a restriktív transzfúziós betegellátás programja bevezetésének hatását elemezte. Nyugat-Ausztrália négy kórházában a vörösvérsejt-koncentrátum, friss fagyasztott plazma és trombocitakoncentrátum használata a vizsgált hat éves periódusban folyamatosan, a periódus végére a kiindulási érték $41 \%$-ára csökkent, mely a készítmények árát figyelembe véve több mint 18 millió ausztrál dollár költségmegtakarítást jelentett (az ún. tevékenység alapú költségmegtakarítást ennél lényegesen többre, 80-100 millió ausztrál dollárra becsülték). A megelőző, majd folyamatos széles körü kampánytevékenységnek köszönhetően az egy egységgel végzett transzfúzió aránya 33,3\%ról fokozatosan $63,7 \%$-ra emelkedett, és a transzfúzió megkezdése előtti átlagos hemoglobinérték 79 g/l-ről 73 g/l-re mérséklődött. Két kórházból származó adatok szerint az infekciós ráta és a szívinfarktus gyakorisága, illetve a kórházi mortalitás és a kórházi ápolás hossza az öszszes kórházban csökkent [49].

\section{Fontosabb megállapitások}

A vértakarékos betegellátás a kórházi minőségi ellátást segíti, a felhasznált vérkészítmények, illetve az ápolási napok számát, így a betegellátás költségét, a transzfúzió kockázatát, a morbiditást - és több adat szerint -, a mortalitást is csökkenti. Törekedni kell arra, hogy a program minél több eleme megvalósítható legyen, mely az effektivitást növeli. Ugyanakkor további vizsgálatoknak kell tisztázniuk, hogy a vértakarékos eljárások közül melyek klinikailag és költség szempontjából a leginkább hatékonyak. A preoperatív anémia kezelése és a restriktív transzfúziós gyakorlat (az elérendő hemoglobinérték és a beadott volument illetően is) biztosan a legfontosabbak közé tartoznak. A program fontos része a vérrendelés adminisztrációja, melynek korszerü, elektronikus formában kell történnie. Ennek jól beazonosíthatóan kell tartalmaznia többek között az igénylő személyét, a rendelés pontos indikációját, a sürgősség mértékét is, mely adatok egy utólagos kontroll számára fontos információval bírnak.

A vértakarékos szemlélet haszna tudományos bizonyítékokon alapul, tehát a mindennapi klinikai gyakorlat része kell legyen, de nem lehet dogma; fontos az individualizált megítélés is.

Kijelenthető, hogy számos európai országban, az Egyesült Államokban, Kanadában és Ausztráliában már kidolgozott, s a klinikai gyakorlatban számos centrumban átültetett program haszna többszörösen bizonyított: a felhasznált vérkészítmények mennyisége csökkenthető, és a betegek eredményesebben kezelhetők. Megvalósítását az Egészségügyi Világszervezet tagállamaiban ösztönzik, az ajánlásokat a programot felvállaló országok széles körben terjesztik. A bemutatás írásban, részben interneten történt (e-learning), rövid összefoglalókat készítettek, a továbbképző előadásokat, kurzusokat mühelymunkával egészítették ki [49, 50]. Hazai bevezetése, terjesztése megkerülhetetlennek tünik. Az ajánlás kidolgozását - mint sok más fejlett országban az érintett aneszteziológusok, sebészek és szülészek, transzfuziológusok, hematológusok, onkológusok és nem utolsó sorban a döntéshozók és finanszírozók bevonásával lenne javasolt végezni. Segítséget jelenthet az Európai Bizottság 2017-ben publikált kiadványa is, mely a program megvalósításának minden fontos aspektusát részletezi [50].

Nyilatkozat: Nyilatkozom arról, hogy a szerzői útmutatót elolvastam. A közlemény korábban más folyóiratban nem jelent meg és máshova beküldésre nem került.

Anyagi támogatás: A közlemény megírása, a kapcsolódó kutatómunka okán anyagi támogatásban nem részesültem.

Érdekeltségek: Nekem mint szerzőnek nincsenek érdekeltségeim.

\section{Irodalom}

[1] Mohamed RS (ed). Blood conservation in the surgical patient. Williams \& Wilkins, Baltimore, 1996.

[2] Network for the Advancement of Patient Blood Management, Haemostasis and Thrombosis. http://www.nataonline.com (Letöltve: 2018. 08. 22).

[3] National Blood Authority. Australia. Patient Blood Management Guidelines. http://www.blood.gov.au/pbm-guidelines (Letöltve: 2018. 09. 11).

[4] Muñoz M, Gómez-Ramírez S, Campos A, et al. Pre-operative anaemia: prevalence, consequences and approaches to management. Blood Transfus. $2015 ; 13: 370-379$.

[5] Musallam KM, Tamim HM, Richards T, et al. Preoperative anaemia and postoperative outcomes in noncardiac surgery: a retrospective cohort study. Lancet 2011; 378: 1396-1407.

[6] Dunne JR, Malone D, Tracy JK, et al. Perioperative anemia: an independent risk factor for infection, mortality, and resource utilization in surgery. J Surg Res. 2002; 102: 237-244.

[7] Elwood NR, Martin AN, Turrentine FE, et al. The negative effect of perioperative red blood cell transfusion on morbidity and mortality after major abdominal operations. Am J Surg. 2018; 216: 487-491.

[8] Fowler AJ, Ahmad T, Phull MK, et al. Systematic review and metaanalysis between preoperative anaemia and mortality after surgery. Br J Surg 2015; 10: 1314-1324.

[9] Goodnough LT, Maniatis A, Earnshaw P, et al. Detection, evaluation, and management of preoperative anaemia in the elective orthopaedic surgical patient: NATA guidelines. Br J Anaesth. 2011; 106: 13-22.

[10] Muñoz M, Acheson AG, Auerback M, et al. International consensus statement on the peri-operative management of anaemia and iron deficiency. Anaesthesia 2017; 72: 233-247.

[11] Dignass A, Farrag K, Stein J. Limitations of serum ferritin in diagnosing iron deficiency in inflammatory conditions. Int J Chronic Dis. 2018; 2018: 9394060 
[12] Froessler B, Palm P, Weber I, et al. The important role for intravenous iron in perioperative patient blood management in major abdominal surgery. A randomized controlled trial. Ann Surg. 2016; 264: 41-46.

[13] Kotzé A, Harris A, Baker C, et al. British committee for standards in haematology guidelines on the identification and management of pre-operative anaemia. Br J Haematol. 2015; 171: 322-331.

[14] Theusinger OM, Kind SL, Seifert B, et al. Patient blood management in orthopaedic surgery - a four year follow up from 2008 to 2011 at the Balgrist University Hospital in Zurich, Switzerland on transfusion requirements and blood loss. Blood Transfus. 2014; 12: 195-203.

[15] Liumbruno GM, Bennardello F, Lattanzio A, et al. Recommendations for the transfusion management of patients in the peri-operative period. I. The pre-operative period. Blood Transfus. 2011; 9 : 19-40.

[16] Australian \& New Zealand Society of Blood Transfusion. Preoperative Autologous Donation (PAD). https://www.anzsbt.org.au/ data/documents/ANZSBTPADstatementApr2015.pdf (Letöltve: 2018. 10. 05.)

[17] Retteghy T. Autologous transfusion. In: Vezendy K. (ed) Transfusion. [Autológ transzfúzió. In: Vezendy K. (szerk.) Transzfúzió] Medicina Könyvkiadó, Budapest, 2015; pp. 11-111.[Hungarian]

[18] Vassallo R, Goldman M, Germain, Lozano M, et al. Preoperative autologous blood donation: waning indications in an era of improved blood safety. Trans Med Rev 2015; 29: 268-275.

[19] Desborough MJ, Oakland KA, Landoni G, et al. Desmopressin for treatment of platelet dysfunction and reversal of antiplatelet agents: a systematic review and meta-analysis of randomized controlled trials. J Thromb Haemost. 2017; 15: 263-272.

[20] Pabinger I, Fries D, Schöchl H, et al. Tranexamic acid for treatment and prophylaxis of bleeding and hyperfibrinolysis. Wien Klin Wochenschr. 2017; 129: 303-316.

[21] Rossaint R, Bouillon B, Cerny V, et al. The European guideline on management of major bleeding and coagulopathy following trauma: fourth edition. Crit Care 201620: 100.

[22] Fredericks C, Kubasiak JC, Mentzer CJ, Yon JR. Massive transfusion: An update for the anesthesiologist. World J Anesthesiol. 2017; 6: 14-21.

[23] Curry N, Foley C, Wong H, et al. Early fibrinogen concentrate therapy for major haemorrhage in trauma (E-FIT 1): results from a UK multi-centre, randomised, double blind, placebo-controlled pilot trial. Crit Care 2018; 22: 164

[24] Curry NS, Davenport R, Pavord S, et al. The use of viscoelastic haemostatic assays in the management of major bleeding: A British Society for Haematology Guideline. Br J Haematol. 2018; 182:789-806.

[25] Innerhofer P, Fries D, Mittermayr M, et al. Reversal of trauma-induced coagulopathy using first-line coagulation factor concentrates or fresh frozen plasma (RETIC): a single-centre, parallel-group, open-label, randomised trial. Lancet Haematol. 2017; 4: e258-e271

[26] Godier A, Greinacher A, Faraoni D. Use of factor concentrates for the management of perioperative bleeding: guidance from the SSC of the ISTH. J Thromb Haemost. 2018; 16: 170-174.

[27] Richman JM, Rowlingson AJ, Maine DN, et al. Does neuraxial anesthesia reduce intraoperative blood loss? A meta-analysis. J Clin Anesth. 2006; $18: 427-435$.

[28] Carson JL, Guyatt G, Heddle NM, et al. Clinical practice guidelines from the AABB: Red blood cell transfusion thresholds and storage. JAMA 2016; 316: 2025-2035.

[29] Roubinian NH, Hendrickson JE, Triulzi DJ, et al. Contemporary risk factors and outcomes of transfusion-associated circulatory overload. Crit Care Med. 2018; 46: 577-585.

[30] Hébert PC, Wells G, Blajchman MA, et al. A multicenter, randomized, controlled clinical trial of transfusion requirements in critical care. N Engl J Med. 1999; 340: 409-417.

[31] Shander A, Javidroozi M, Naqvi S, et al. An update on mortality and morbidity in patients with very low postoperative hemoglobin levels who decline blood transfusion (CME). Transfusion 2014; 54: 2688-2695.

[32] Holst LB, Haase N, Wetterslev J, et al. Group TT, Scandinavian Critical Care Trials: Lower versus higher hemoglobin threshold for transfusion in septic shock. N Engl J Med. 2014; 371: 1381-1391.

[33] Carson JL, Terrin ML, Noveck H, et al. Liberal or restrictive transfusion in high-risk patients after hip surgery. N Engl J Med. 2011; 365: 2453-2462.

[34] Lacroix J, Hébert PC, Hutchison JS, et al. Transfusion strategies for patients in pediatric intensive care units. N Engl J Med. 2007; 356: 1609-1619.

[35] Villanueva C, Colomo A, Bosch A, et al. Transfusion strategies for acute upper gastrointestinal bleeding. N Engl J Med 2013; 368: $11-21$.

[36] East JM, Viau-Lapointe J, McCredie VA. Transfusion practices in traumatic brain injury, Curr Opin Anesthesiol. 2018; 31: 219-226.

[37] Shander A, Van Aken H, Colomina MJ, et al. Patient blood management in Europe. Br J Anaesth. 2012; 109: 55-68.

[38] Muñoz M, Franchini M, Liumbruno GM. The post-operative management of anaemia: more efforts are needed. Blood Transfus. 2018; 16: 324-325.

[39] Khalafallah AA, Yan C, Al-Badri R, et al. Intravenous ferric carboxymaltose versus standard care in the management of postoperative anaemia: a prospective, open-label, randomised controlled trial. Lancet Haematol. 2016; 3: e415-425.

[40] Daoud E, Nakhla E, Sharma R. Q: Is iron therapy for anemia harmful in the setting of infection? Cleve Clin J Med. 2011; 78: 168-170.

[41] Liumbruno GM, Bennardello F, Lattanzio A, et al. Recommendations for the transfusion management of patients in the peri-operative period. III. The post-operative period. Blood Transfus. 2011; 9: 320-335.

[42] Hare GM, Mu A, Romaschin A, et al. Plasma methemoglobin as a potential biomarker of anemic stress in humans. Can J Anaesth. 2012; 59: 348-356.

[43] Spolverato G, Kim Y, Ejaz A, et al. Effect of relative decrease in blood hemoglobin concentrations on postoperative morbidity in patients who undergo major gastrointestinal surgery. JAMA Surg. 2015; 150: 949-956.

[44] Zeroual N, Samarani G, Gallais J, et al. ScvO2 changes after redblood-cell transfusion for anaemia in cardiothoracic and vascular ICU patients: an observational study. Vox Sang. 2018; 113: 136142.

[45] Surve RM, Muthuchellappan R, Rao GS, Philip M. The effect of blood transfusion on central venous oxygen saturation in critically ill patients admitted to a neurointensive care unit. Transfus Med. 2016; 26: 343-348.

[46] Abraham I, Sun D. The cost of blood transfusion in Western Europe as estimated from six studies. Transfusion 2012; 52: 19831988.

[47] Gombotz H, Hofmann A. [Patient Blood Management: three pillar strategy to improve outcome through avoidance of allogeneic blood products]. Anaesthesist 2013; 62: 519-527.

[48] Meybohm P, Herrmann E, Steinbicker AU, et al. Patient blood management is associated with a substantial reduction of red blood cell utilization and safe for patient's outcome: a prospective, multicenter cohort study with a noninferiority design. Ann Surg. 2016; 264: 203-211.

[49] Leahy MF, Hofmann A, Towler S, et al. Improved outcomes and reduced costs associated with a health-system-wide patient blood management program: a retrospective observational study in four major adult tertiary-care hospitals. Transfusion 2017; 57: 13471358.

[50] European Commission. Directorate General for Health and Food Safety Health Programme. Supporting Patient Blood Management (PBM) in the EU. A Practical Implementation Guide for Hospitals. https://ec.europa.eu/health/sites/health/files/blood_ tissues_organs/docs/2017_eupbm_hospitals_en.pdf (Letöltve: 2018. 09. 14.). 


\section{Meghívó}

A Magyar Hematológiai és Transzfuziológiai Társaság és a Somogy Megyei Kaposi Mór Oktató Kórház az

\section{Molekuláris Hematológia Konferenciát}

\section{9. február 28. - március 2. között}

Kaposváron rendezi meg.

A konferencia helyszíne: Kapos Hotel - Kaposvár, Kossuth tér

A konferencián való részvétel 35 év alatt ingyenes, 35 év felett 1 éjszaka szállással $25000 \mathrm{Ft}$,

2 éjszaka szállással $35000 \mathrm{Ft}$.

Kérjük a jelentkezési határidő pontos betartását Önök és a munkatársaik esetében is.

Jelentkezési határidő: 2019. február 1.

Absztrakt leadási határideje: 2019. január 15.

Jelentkezéseket a MOLHEMA2019@kmmk.hu e-mail címen várjuk.

Várjuk szeretettel!

\section{Tudományos információ}

Dr. Egyed Miklós

Somogy Megyei Kaposi Mór Oktató Kórház
Tel.: 82/501-341, 30/9021-067

E-mail: dregyedmiklos@yahoo.com
Tervezett program

\begin{tabular}{c}
\hline 2019. február 28. \\
\hline 16:00-18:00 Aktualitások a \\
molekuláris biológiában \\
19:00- $\quad$ Vacsora
\end{tabular}

\begin{tabular}{c}
\hline 2019. március 1. \\
\hline 9:45-10:00 Megnyitó \\
10:00-12:00 Elméleti blokk sejt- \\
felszíni receptorok, jelátvitel \\
az új adatok tükrében \\
12:00-13:00 Ebéd \\
13:00-15:00 Lymphoma blokk \\
15:00-15:30 Kávészünet \\
15:30-17:30 CLL blokk \\
18:00- $\quad$ Vacsora
\end{tabular}

\begin{tabular}{ll}
\hline 2019. március 2. \\
\hline 8:30-10:30 & Myeloma blokk \\
10:30-11:00 & Kávészünet \\
11:00-12:30 & MDS, akut leukémia blokk \\
12:30-13:00 & Konferencia zárása \\
$12: 30-$ & Ebéd \\
& \\
&
\end{tabular}

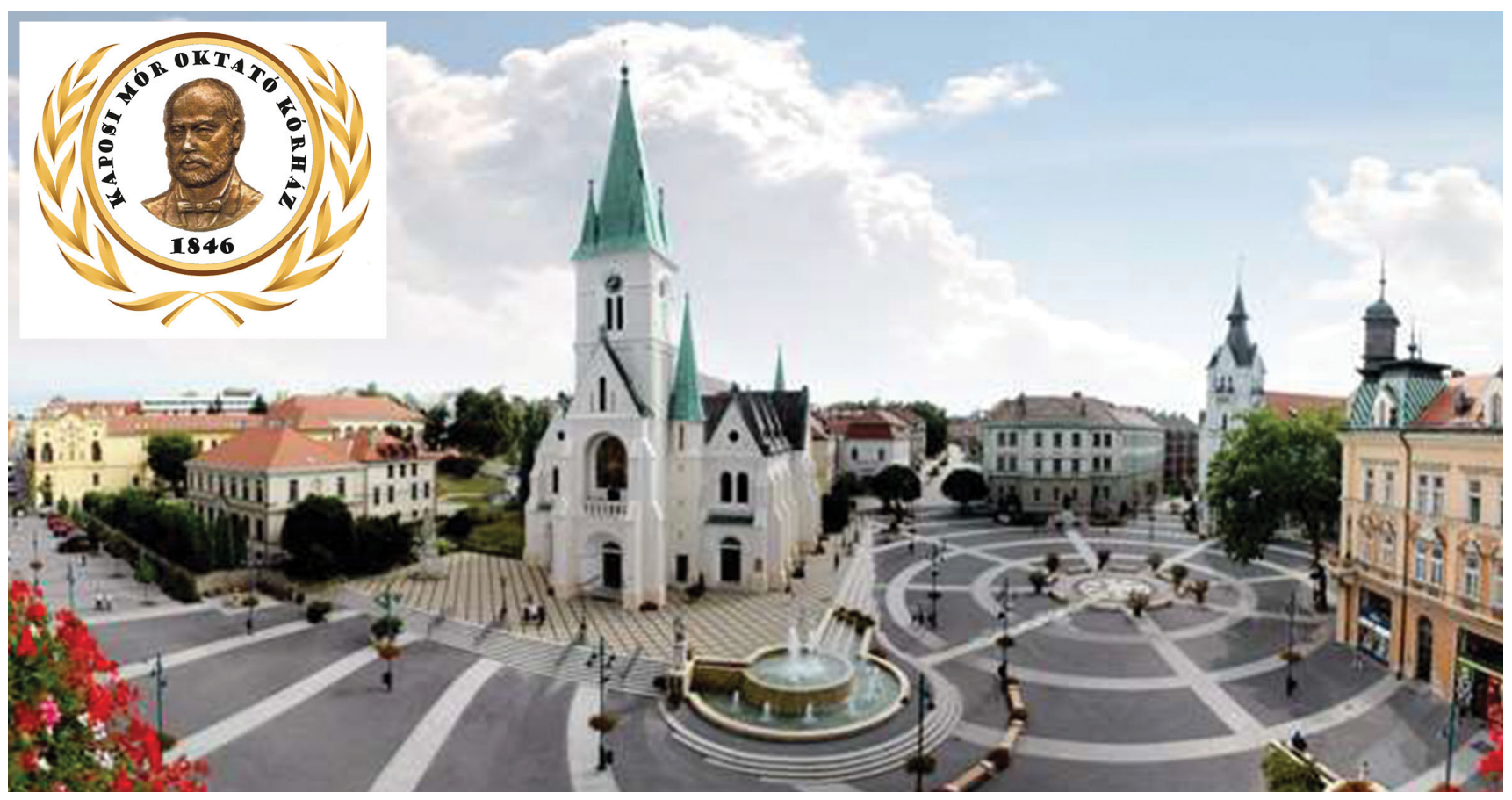

